Sri Lankan J. Biol. 2021, 6 (1): 15 - 30

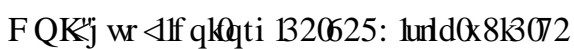

KUSVUIRLFIGIRU [0000-0001-5802-5516

Research Article

Open Access

\title{
Production of fermented soymilk and its preservation using essential oils from the leaves of Hoslundia opposita
}

Saliu, B.K. ${ }^{1 *}$, Etim, S.E. ${ }^{1}$, Yusuf, H.A. ${ }^{1}$, Zakariyah, R.F. ${ }^{1}$, Sule, I.O. ${ }^{1} \&$ Agbabiaka, T.O. ${ }^{1}$

${ }^{1}$ Department of Microbiology, University of Ilorin, Ilorin. Nigeria

\begin{abstract}
Fermented Soymilk (FSM), a protein rich beverage is highly prone to microbial contamination. Its preservation is therefore, key to its availability and safety. Soymilk was prepared by aqueous extraction of soybeans and allowed to ferment spontaneously. Samples of FSM were treated with essential oils from the leaves of Hoslundia opposita (LEOHO) at 5\% and 10\% (v/v) and stored at ambient temperature. The organoleptic, $\mathrm{pH}$, microbiological and biochemical qualities of the samples were evaluated periodically during storage. The protein content was significantly $(\mathrm{p}<0.05)$ improved from $8.18 \pm 0.06 \%$ to $12.62 \pm 0.12 \%$ by fermentation. Compared to the untreated, samples treated with LEOHO had higher sensory ratings. The $\mathrm{pH}$ of the samples decreased from 6.9 to 5.7 during fermentation; and further to 4.9 during storage. Overall, the bacterial load was significantly $(\mathrm{p}<0.05)$ reduced (by up to $80.04 \%$ ) during storage; while the fungal load was reduced to zero immediately after fermentation. The bacterial isolates were Bacillus wiedmannii FSL W8-016, Micrococcus luteus NCTC 2665, Lactobacillus algidus M6A, Lactobacillus sakei NBRC 15893, Lactobacillus apodemi ASB1, Shigella sp., Staphylococcus aureus and Escherichia coli, while the fungi were Candida parapsilosis IQMustafa31, Penicillium citrinum, Aspergillus flavus and Fusarium verticilloides. All the bacterial isolates were sensitive to LEOHO with the zone of inhibition ranging from $10.00 \pm 1.00 \mathrm{~mm}$ to $46.33 \pm 1.53 \mathrm{~mm}$. This study shows that LEOHO was effective in preserving the sensory and nutritional value as well as reducing the microbial population of FSM. LEOHO is therefore recommended as a preservative to increase the shelf life of FSM.
\end{abstract}

Received: 20 Jan 2020

Accepted: 07 Aug 2020

Key words:

Fermentation

Soymilk

Hoslundia opposita

Shelf life

*Corresponding author: saliu.bk@unilorin.edu.ng

Tel: 08023093294

\section{Introduction}

Soybean is the seed of the leguminous plant, Glycine max. It has been identified over the years as a cheap and readily available source of protein. It is particularly rich in lysine, arginine, cysteine, leucine, and methionine amino acids (Rastogi and Singh, 1989; Riaz, 1999), minerals and vitamins such as calcium, iron, vitamin A, riboflavin and other trace elements (Adegoke et al., 2012). Its lipid content is rich in polyunsaturated fatty acids such as linoleic acid and linolenic acid (Agboke et al., 2011). Further, it contains a low amount of fat with no cholesterol and therefore, is known to reduce the risk of heart disease.

Soybean is processed to soymilk by aqueous extraction of whole beans. Soymilk can serve as a substitute for milk from cow, sheep, goat etc. It is safe for people who are allergic to milk protein, lactose intolerance and for children with galactosemia (Obadina et al., 2013; Subrota et al., 2013). Its consumption is however limited due to the presence of undesirable beany flavour attributed to several factors including the presence of aldehydes and alcohols such as n-hexanal, flatulence caused by indigestible galactooligosaccharides, and digestive problems associated with the presence of raffinose and stachyose (Subrota et al., 2013; Horáčková et al., 2015). Fermentation has been used to overcome the problems associated with soymilk by removing the beany flavour (Wang et al., 2006), making the protein contents more digestible (Ishibashi and Shimamura, 1993), and reducing oligosaccharides, raffinose and stachyose thereby improving its nutritional characteristics and acceptance. 
Soybeans and soymilk have been fermented traditionally in many parts of the world, to products such as Buckwheat sokseongjang, Cheonggukjang, Miso, Douchi, Natto, Kinema, Tempeh, (MoraEscobedo et al., 2018), soy cheese (Schnurer and Magnusson, 2005), soymilk-kefir (Silva et al., 2018), soy yoghurt (Osundahunsi et al.,2007) etc. Fermented soymilk (FSM) may contain probiotic lactic acid bacteria which can confer health benefits such as high antioxidant capacity, production of antimicrobial metabolites, improved digestibility and reduced metabolic disorders on the consumers (Zielinska and Kolozyn-Krajewska, 2018). Soyyoghurt has a yoghurt-like flavour and can serve as a refreshing and nutritious beverage. It is however prone to microbial contamination. Its preservation is therefore key to its availability and safety.

Preservation can be achieved using physical methods such as exposing to extreme temperature, radiation etc. Chemical preservation is very common with beverage foods such as the FSM. However, only chemicals that have the GRAS status are permitted in foods. Such chemicals could be synthetic or natural. The use of most synthetic chemicals is being discouraged due to the associated health risks such as carcinogenic properties etc (Gutlekin et al., 2015). This highlights the importance of using natural chemicals such as essential oils.

Essential oils comprise a complex combination of bioactive chemicals mostly terpenes, terpenoids, other aromatic and aliphatic compounds. Many essential oils exhibit antibacterial, antifungal, antiviral and insecticidal activities and are being used both in medicine and as food additives (Djenane et al., 2012; Stefanakis et al., 2013). Usually, two or three of the numerous chemical compounds which are present in a relatively large quantity of about $20-70 \%$ account for the antimicrobial activities of the oils (Pandey et al., 2015). Hoslundia opposita which is commonly known as orange-bird berry is a perennial herbaceous plant with tasty fruits that attracts birds but has an unpleasant scent that repels bees (Sadri, 2017).The essential oils from the leaves of Hoslundia opposita LEOHO) contains 1, 8-cineole, $\alpha$ - terpineol, sabinene, thymol and car-3-ene (Usman et al., 2010; Akolade et al., 2014; Babarinde et al., 2017) which have been shown to exhibit antimicrobial activities against spoilage and pathogenic bacteria and fungi (Gundidza et al., 1992). There is however a paucity of information on its use as food preservatives.

Production of dairy milk in Nigeria is rudimentary and the populace depends largely on foreign supplies. The health benefits derivable from soymilk in addition to its nutritional composition makes it a suitable substitute for dairy. The soybean plant thrives well in Nigeria with a yield as high as 12,951 hectograms per hectare and a further capacity to increase production (www.factfish.com). Processing of soybeans to soymilk requires simple and cheap technology and fermentation can be used to overcome the problem of acceptability due to the beany flavour, flatulence and digestive issues. In addition, preservation with the use of natural products such as essential oils can ameliorate the risk associated with chemical preservatives. This work therefore focused on the production of fermented soymilk, and its preservation using the essential oils from the leaves of Hoslunda opposita.

\section{Materials and Methods}

\subsection{Soymilk production}

Soybeans were purchased from the market, cleaned, dehulled, wet milled into a slurry, sieved through a muslin cloth and boiled at $100{ }^{\circ} \mathrm{C}$ for 15 minutes. The resultant soymilk was allowed to cool after which samples were withdrawn for prefermentation analysis which included sensory evaluation, proximate analysis and $\mathrm{pH}$ measurement.

\subsection{Fermentation}

The soymilk was distributed into four $250 \mathrm{ml}$ Erlenmeyer's flasks in $100 \mathrm{ml}$ portions. Sucrose, $8 \% \mathrm{w} / \mathrm{v}$ was added into two of the flask while the other two were not supplemented. One flask from each of the supplemented and non-supplemented was incubated on a rotatory shaker at $150 \mathrm{rpm}$ while the others were left on work bench. The soymilk samples were allowed to ferment for 24 hours during which samples were withdrawn every 3 hours for the analysis.

\subsection{Preservation}

The essential oils from the leaves of Hoslundia opposita (LEOHO) was prepared by hydro distillation using a Clevenger-type apparatus. The oil was added to fermented soymilk (FSM) at 5\% and $10 \%(\mathrm{v} / \mathrm{v})$ in sterile sample bottles. All samples (treated and untreated) were stored at $28 \pm 2^{\circ} \mathrm{C}$ (room temperature) and aliquots were withdrawn periodically for analysis

\subsection{Sensory evaluation}

A panel of five volunteers evaluated the sensory quality using five-point Hedonic scale. Attributes evaluated for the soymilk were colour, odour, taste and consistency.

\subsection{Proximate analysis}

The moisture, ash, crude fat, crude fibre, protein and carbohydrate contents were evaluated using standard procedures (AOAC, 2003). 


\subsection{Titratable acidity}

Samples were titrated against $\mathrm{NaOH}$ using standard procedures (AOAC, 2003).

\section{$2.7 \mathrm{pH}$}

The $\mathrm{pH}$ of the samples was measured periodically during fermentation using a digital hand held $\mathrm{pH}$ meter. The $\mathrm{pH}$ meter was standardized to $\mathrm{pH} 4.0$, 7.0 and 9.0 using appropriate buffers.

\subsection{Microbiological analysis}

Bacteria were isolated on Nutrient Agar, de Man Rogosa Sharpe (MRS) medium and McConkey Agar; and fungi on Potato Dextrose Agar using pour plate method. Briefly, $1 \mathrm{~mL}$ of sample was added to $9 \mathrm{~mL}$ sterile distilled water in a test tube and serially diluted up to $10^{-3}$. Aliquots, $100 \mu \mathrm{L}$ from the last diluents was placed in the sterile plate, $15 \mathrm{~mL}$ of molten agar was poured on it and the plate was covered immediately. The sample was mixed with agar by rocking the plate gently on the work bench. Plates were incubated at $37^{\circ} \mathrm{C}$ for bacterial isolation and $28{ }^{\circ} \mathrm{C}$ for fungi. After growth, a colony counter was used to enumerate total aerobic bacteria on Nutrient Agar, lactic acid bacteria on de Man Rogosa Sharpe (MRS) medium and enteric bacteria on McConkey Agar. Fungal colonies were also enumerated on PDA. Bacterial identification was based on morphological, biochemical and molecular characterization using standard procedures. Molds were identified by morphology while for the yeasts, physiological and molecular characterization was used in addition.

\subsection{Antimicrobial sensitivity test}

The sensitivity test was performed using the agar well diffusion method. Aliquots, $100 \mu \mathrm{L}$ of isolate at 0.5 McFarland standard was inoculated on Mueller Hinton agar plates using the spread plate method. Wells measuring $6 \mathrm{~mm}$ with a space not less than $20 \mathrm{~mm}$ around it, were bored in the seeded agar. The LEOHO was diluted using Tween 80 and loaded into wells at 25\%, 50\% and 100\%. Tween 80 was loaded as the control. Plates were incubated at $37^{\circ} \mathrm{C}$ and observed after 24 hours for bacterial growth and clearance around wells. Diameter zones of clearance were measured at three planes around wells.

\subsection{Statistical Analysis}

Data were recorded as means with standard deviations of triplicate measurements. ANOVA was conducted using SPSS 20 software.

\section{Results}

\subsection{Proximate composition of soybeans}

The nutritional composition of the soybean samples is given in Table 1.

\subsection{Sensory quality of soymilk}

The taste rating of the sugar supplemented soymilk samples (SSM) was significantly ( $<<0.05$ ) higher than those of the non-supplemented samples (PSM). Apart from this, there was no significant difference $(p<0.05)$ in the consumer ratings of the other sensory attributes between the SSM and PSM (Table 2) by a five member panel.

\subsection{Changes in the $p H$ of soymilk during fermentation}

The $\mathrm{pH}$ of soymilk decreased during fermentation from a value near neutral to as low as 5.7 within 24 hours (Figure 1).

\subsection{Bacterial growth in soymilk samples during} fermentation

The growth of lactic acid bacteria, enteric bacteria and total bacteria represented as the number of colonies on de Man Rogosa Sharpe (MRS) agar, McConkey agar and Nutrient agar are presented in Figures 2, 3 and 4 respectively.

3.5 Growth of fungi in soymilk samples during fermentation

Fungal growth, measured as the number of colonies on Potato Dextrose agar is presented in figure 5.

Table 1: Proximate composition of soybeans samples

\begin{tabular}{ll}
\hline Parameters & Soybeans \\
\hline Moisture (\%) & $7.93 \pm 0.09$ \\
Ash (\%) & $3.83 \pm 0.01$ \\
Carbohydrate (\%) & $28.09 \pm 0.5$ \\
Total Protein (\%) & $41.48 \pm 0.08$ \\
$\begin{array}{ll}\text { Crude Lipids (\%) } \\
\text { Crude fibre (\%) }\end{array}$ & $11.83 \pm 0.69$ \\
$\begin{array}{l}\text { Calorific Value KJ/100g } \\
\text { Metabolizable Energy Kcal/kg }\end{array}$ & $6.83 \pm 0.02$ \\
$\begin{array}{l}\text { Metabolizable Energy Protein } \\
\text { ratio }\end{array}$ & $3.26 \pm 0.11$ \\
Titrable acidity (\%) & \\
\hline
\end{tabular}

Values are means \pm standard deviations of three independent analysis. 


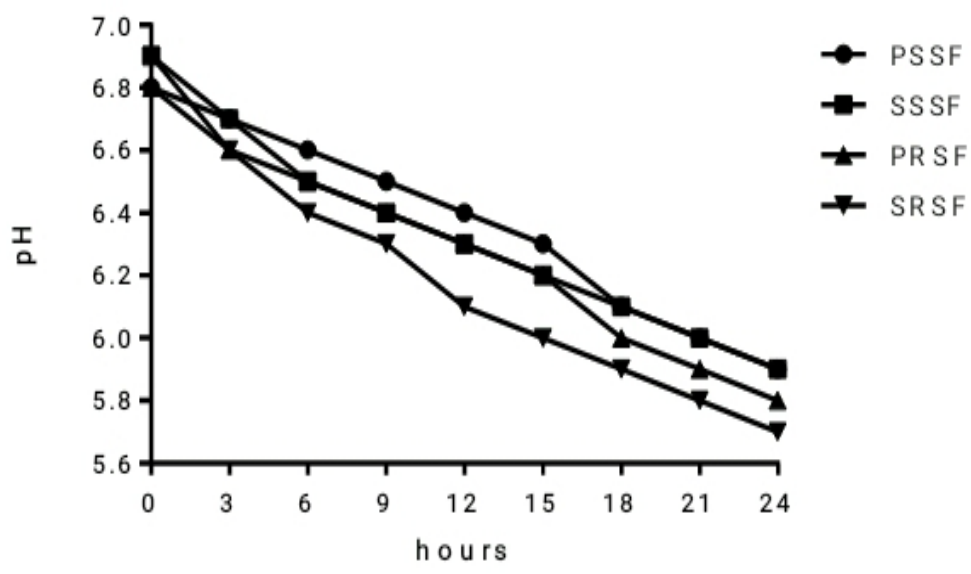

Figure 1: Changes in the pH of soymilk samples during fermentation

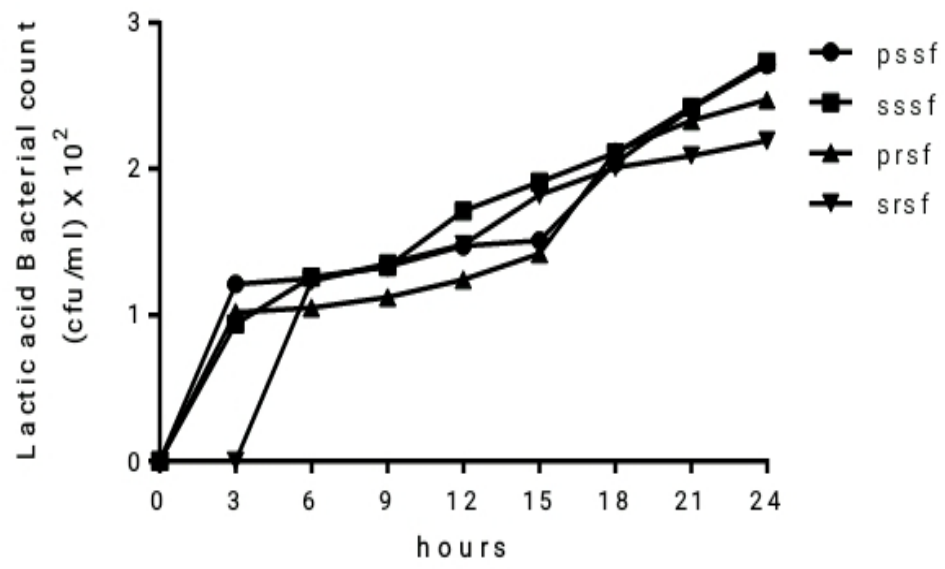

Figure 2: Growth of Lactic acid bacteria in soymilk samples during fermentation

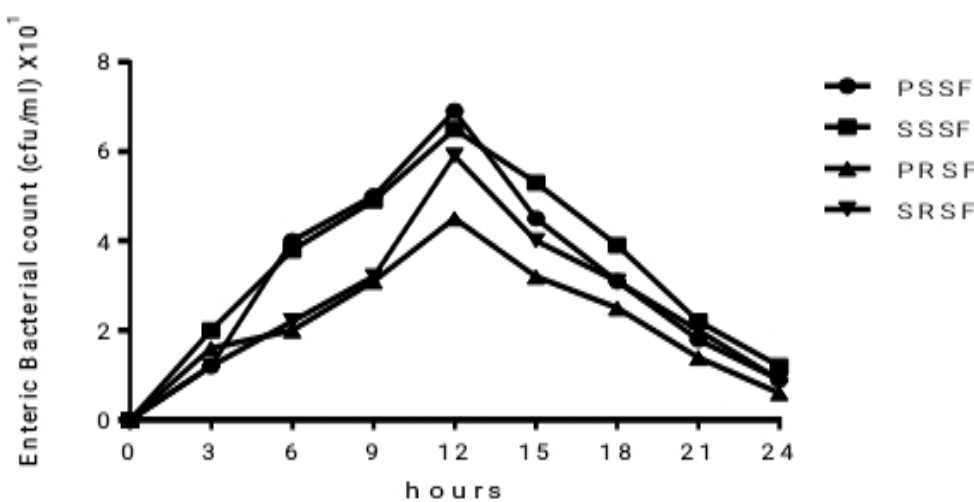

Figure 3: Growth of Enteric bacteria in soymilk samples during fermentation
PSSF: Non supplemented soymilk fermented on stationary bench PRSF: Non supplemented soymilk fermented on rotary shaker SSSF: Soymilk supplemented with sucrose and fermented on stationary bench

SRSF: Soymilk supplemented with sucrose and fermented on rotary shaker

PSSF: Non supplemented soymilk fermented on stationary bench PRSF: Non supplemented soymilk fermented on rotary shaker SSSF: Soymilk supplemented with sucrose and fermented on stationary bench

SRSF: Soymilk supplemented with sucrose and fermented on rotary shaker
PSSF: Non supplemented soymilk fermented on stationary bench PRSF: Non supplemented soymilk fermented on rotary shaker SSSF: Soymilk supplemented with sucrose and fermented on stationary bench

SRSF: Soymilk supplemented with sucrose and fermented on rotary shaker 


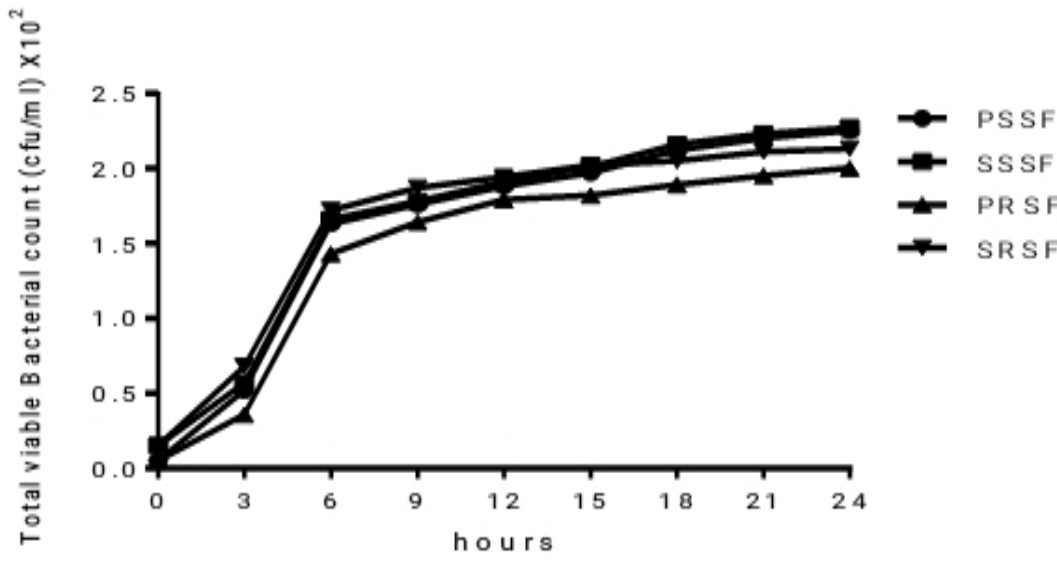

Figure 4: Total bacteria growth in soymilk samples during fermentation

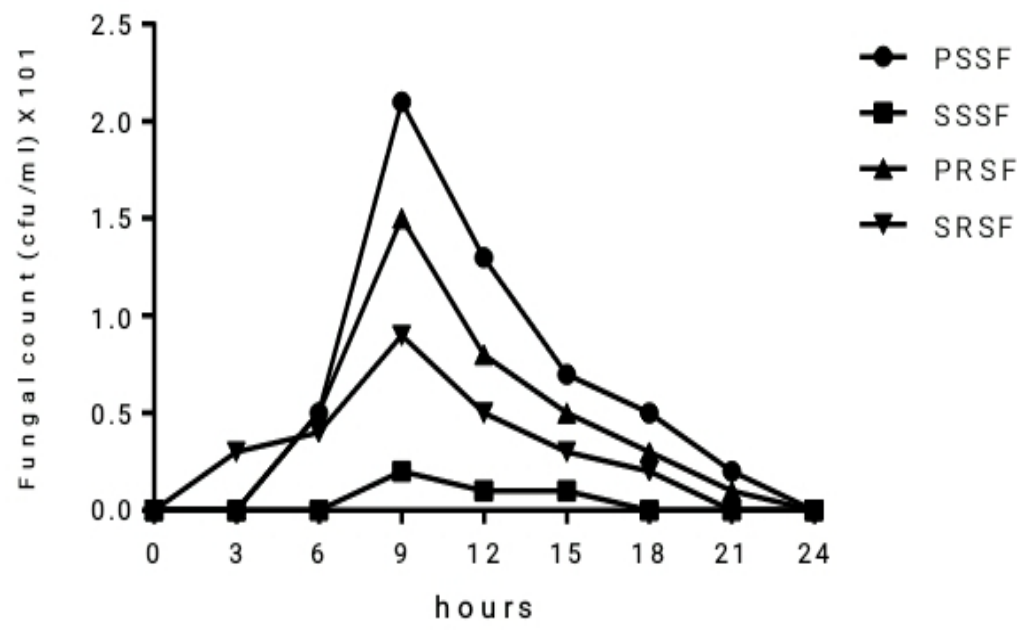

PSSF: Non supplemented soymilk fermented on stationary bench PRSF: Non supplemented soymilk fermented on rotary shaker

SSSF: Soymilk supplemented with sucrose and fermented on stationary bench

SRSF: Soymilk supplemented with sucrose and fermented on rotary shaker
PSSF: Non supplemented soymilk fermented on stationary bench PRSF: Non supplemented soymilk fermented on rotary shaker SSSF: Soymilk supplemented with sucrose and fermented on stationary bench SRSF: Soymilk supplemented with sucrose and fermented on rotary shaker

Figure 5: Total fungal growth in soymilk samples during Fermentation

Table 2: Sensory evaluation of soymilk samples

\begin{tabular}{llllll}
\hline Samples & Taste & Odor & Texture & Color & $\begin{array}{l}\text { Overall } \\
\text { Acceptance }\end{array}$ \\
\hline SSM & $4.3 \pm 0.3^{\mathrm{a}}$ & $4.6 \pm 0.2^{\mathrm{a}}$ & $4.6 \pm 0.2^{\mathrm{a}}$ & $4.8 \pm 0.1^{\mathrm{a}}$ & $4.73 \pm 0.1^{\mathrm{a}}$ \\
PSM & $3.4 \pm 0.2^{\mathrm{b}}$ & $4.4 \pm 0.2^{\mathrm{a}}$ & $4.4 \pm 0.2^{\mathrm{a}}$ & $4.8 \pm 0.1^{\mathrm{a}}$ & $4.2 \pm 0.2^{\mathrm{b}}$ \\
\hline
\end{tabular}

Values represent mean of ratings by five member panel \pm standard deviations. Values for overall acceptance are mean \pm standard deviations of all sensory evaluations taken. Values in the same column with different superscripts are significantly $(\mathrm{P}<0.05)$ different. SSM=Soymilk containing $8 \mathrm{~g}$ of sucrose, PSM=Soymilk without sucrose.

\subsection{Microbial isolates}

A total of 12 microorganisms comprising 8 bacteria and 4 fungi were isolated and characterized. These are described below.

\subsubsection{Bacteria}

The morphological and physiological characteristics of the isolates are presented in Table 3. The bacteria were identified after analysis of 
their sequences using the BLASTN tool (www.ncbi.nlm.nih.gov:80/BLASTN/) (Table 4)

\subsection{2: Fungi}

The morphological characters of the fungal isolates on which their identification was based is presented in table 5. The fungi were identified as Candida parapsilosis, Aspergillus flavus, Penicillium critinum and Fusarium verticilloides. The yeast, Candida parapsilosis was identified to the strain level along with some of the bacterial isolates (Table 4)

3.7: Effect of fermentation on the proximate Composition of Soymilk Samples

The changes that occurred with the soymilk samples after fermentation is presented in table 6

3.8: Effect of the leaf essential oil of Hoslundia opposita (LEOHO) on the sensory quality of fermented soymilk during storage

The acceptance rating of the fermented soymilk remained high up to the $8^{\text {th }}$ day of storage for all the samples that were treated with LEOHO while the control sample was rated low from the $2^{\text {nd }}$ day onwards (Table 7).

3.9: Effect of the leaf essential oil of Hoslundia opposita on the bacterial load of fermented soy milk samples during storage

There was significant $(\mathrm{p}<0.05)$ reduction in the bacterial load of fermented soymilk samples in the first 24 hours after treatment with LEOHO. The reduction in bacterial load was significantly ( $\mathrm{p}<$ 0.05 ) more pronounced in the samples that were treated with $10 \%$ oil compared to that treated with $5 \%$. Counts were kept low throughout the storage although there were significant $(\mathrm{p}<0.05)$ increases after the initial reduction. In comparison, counts from the control sample increased significantly ( $\mathrm{p}$ 0.05 ) with the storage period and the sample deteriorated between the $4^{\text {th }}$ and $5^{\text {th }}$ day to an extent that they had to be discarded and hence bacterial loads were not determined (Table 8).

3.10: Effect of the leaf essential oil of Hoslundia opposita on the fungal load of fermented soy milk samples during storage

No fungi were recovered from most of the soymilk samples after fermentation. Sparse growth however occurred during storage. Fungal growth inhibition by the $10 \%$ LEOHO was significantly ( $p<0.05$ ) higher than that in the $5 \%$ oiland more significant compared to the untreated samples (Table 9).

3.11: Sensitivity of bacterial isolates to the leaf essential oil of Hoslundia opposita

All the isolated bacteria were sensitive to the LEOHO at the lowest concentration used (25\%). The oil had cidal effects on all the isolates at $100 \%$ concentration; on four and three of the isolates at
$50 \%$ and $25 \%$, respectively, while a static effect was exerted on the others (Table 10).

\section{Discussion}

The total protein content of soybeans was recorded as $41.48 \%$ in the present study which falls within earlier reported values (Rathi et al., 2015; Etiosa et al., 2017; Useh et al., 2017), corroborating the claims that soybeans are rich sources of protein and further justifies its candidature in the production of milk.

The changes that occurred in the $\mathrm{pH}$ of soymilk samples during the fermentation process are indicative of the presence of microorganisms such as the lactic acid bacteria (LAB) which ferment sugar in the milk samples to produce organic acids mostly lactic acid. A similar $\mathrm{pH}$ decrease was reported by Obadina et al. (2013) during the fermentation of soy nono. The highest reduction occurred in sample D which was supplemented with sugar and fermented on rotary shaker. This shows that sugar supplementation may be necessary not only for taste enhancement but also to aid fermentation since the fermenting organisms require sugar for metabolism.

The growth of lactic acid bacteria during fermentation was exponential within the first 3 hours. This leaves out the lag phase of growth and thus can be attributed to the high presence of the LAB on the soybean used to produce the soymilk. Since the soybeans serve as the source of the LAB, the organisms may have adjusted to the nutrient accounting for the lack of the lag phase of growth. This concept can also lead to the efficient production of lactic acid which is a primary metabolite of the LAB (Figure 2). In addition, the growth of LAB in the soymilk sample indicates its rich nutrient composition since the organisms are fastidious.

The enteric bacteria grew steadily for the first 12 hours of incubation and dropped to almost zero within the next 12 hours, this being attributed to the production of antibacterial compounds such as lactic acid, hydrogen peroxide and bacteriocins in the fermentation medium which causes inhibition of this category of organisms and thereby facilitating the proliferation of the LAB.

The total bacterial growth as obtained on nutrient agar may have left out the fastidious LAB, and hence follows the growth curve pattern in a closed system (Willey et al., 2008). The organisms grew slowly during the first 3 hours of fermentation but exponentially thereafter for the next 3 hours. There was however no significant increase in growth thereafter until fermentation was terminated. 
Table 3: Morphological and biochemical characterization of Isolates from Soymilk and Fermented Soymilk samples

\begin{tabular}{|c|c|c|c|c|c|c|c|c|}
\hline \multirow[t]{2}{*}{ Characters } & \multicolumn{8}{|l|}{ Isolates } \\
\hline & BA & BB & $\mathrm{BC}$ & $\mathrm{BD}$ & $\mathrm{BE}$ & $\mathrm{BF}$ & BG & $\mathrm{BH}$ \\
\hline \multicolumn{9}{|c|}{ Colony Characteristics } \\
\hline Shape & Circle & Circle & Swarm & Irregular & Circle & Circle & Circle & Circle \\
\hline Margin & Entire & Entire & Undula & Undula & Entire & Entire & Entire & Entire \\
\hline Elevat & Raise & Convex & Flat & Flat & Convex & Conve & Convex & Convex \\
\hline Size & Small & Small & Spread & Large & Small & Large & Small & Small \\
\hline Texture & Smooth & Smooth & Smoot & Rough & Smooth & Rough & Smooth & Smooth \\
\hline Appear & Dull & Shiny & Shiny & Dull & Shiny & Shiny & Shiny & Shiny \\
\hline Pigment & Cream & Cream & Cream & Cream & Yellow & Golden & Greyish & Cream \\
\hline Optical & Transluc & Transluc & Opaqu & Transluc & Opaqu & Opaqu & Transluc & Transluc \\
\hline \multicolumn{9}{|c|}{ Cellular Morphology } \\
\hline Gram & + & + & + & + & + & + & - & - \\
\hline Shape & Rod & Rod & Rod & Rod & Coccus & Coccus & Rod & Rod \\
\hline Arrang & Single & Single & Single & Single & Tetrad & Cluster & Single & Single \\
\hline Motility & - & - & - & + & - & - & - & + \\
\hline Spore & - & - & - & + & - & - & - & - \\
\hline \multicolumn{9}{|c|}{ Biochemical Characteristics } \\
\hline$\overline{\text { Urease }}$ & + & + & + & + & + & + & - & - \\
\hline Catalase & - & - & - & + & + & + & + & + \\
\hline Starch & - & - & - & + & - & - & - & - \\
\hline Oxidase & - & - & - & - & + & - & - & - \\
\hline Citrate & - & - & - & + & + & + & & - \\
\hline Gelatin & - & + & + & + & + & + & - & - \\
\hline Indole & - & - & - & - & - & - & - & + \\
\hline MR & - & - & - & + & + & + & + & + \\
\hline VP & - & - & - & + & - & - & - & - \\
\hline Nitrate & - & - & - & + & + & + & + & + \\
\hline Mannito & + & - & + & + & - & + & + & + \\
\hline TSI & $\mathrm{K} / \mathrm{A}$ & $\mathrm{K} / \mathrm{A}$ & $\mathrm{K} / \mathrm{A}$ & $\mathrm{K} / \mathrm{A}$ & $\mathrm{K} / \mathrm{A}$ & $\mathrm{A} / \mathrm{A}$ & $\mathrm{K} / \mathrm{A}$ & A/A, G \\
\hline $\mathrm{H}_{2} \mathrm{~S}$ & - & - & - & - & - & - & - & - \\
\hline $\mathrm{NaCl}$ & + & - & + & + & - & + & & + \\
\hline Gr10 & + & + & + & + & + & + & + & + \\
\hline Gr45 & + & + & - & - & + & - & + & - \\
\hline Casein & + & + & + & + & + & + & - & - \\
\hline $\begin{array}{l}\text { Probable } \\
\text { identity }\end{array}$ & $\begin{array}{l}\text { Lactobaci } \\
\text { llus sakei }\end{array}$ & $\begin{array}{l}\text { Lactobaci } \\
\text { llus } \\
\text { algidus }\end{array}$ & $\begin{array}{l}\text { Lactoba } \\
\text { cillus } \\
\text { apodemi }\end{array}$ & $\begin{array}{l}\text { Bacillus } \\
\text { wiedmanni } \\
i\end{array}$ & $\begin{array}{l}\text { Micrococ } \\
\text { cus luteus } \\
\text { strain }\end{array}$ & $\begin{array}{l}\text { Staphyloco } \\
\text { cus aureus }\end{array}$ & $\begin{array}{l}\text { Shigell } \\
\text { a sp. }\end{array}$ & $\begin{array}{l}\text { Escheric } \\
\text { hia coli }\end{array}$ \\
\hline
\end{tabular}

+ denotes Positive, - denotes Negative, Elevat - Elevation, Arrang - Arrangement, MR - Methyl Red, VP VogesProskauer, Mannito - Mannitol, TSI - Triple Sugar Iron, $\mathrm{H}_{2} \mathrm{~S}$ - Hydrogen Sulphite, $\mathrm{NaCl}$ - Growth in $6.5 \%$ Sodium chloride solution, Gr10 - Growth at $10^{\circ} \mathrm{C}$, Gr45 - Growth at $45^{\circ} \mathrm{C}, \mathrm{K}$ - Alkaline, A - Acid, G Gas,

Table 4: Molecular characterization of Isolates from Soymilk and Fermented Soymilk samples

\begin{tabular}{lllll}
\hline Isolate & Organism & $\begin{array}{l}\text { Number of } \\
\text { Bases }\end{array}$ & $\begin{array}{l}\text { Identity } \\
(\%)\end{array}$ & Accession Number \\
\hline BA & Lactobacillus sakei strain NBRC 15893 & 1012 & 91 & NR 113821.1 \\
BB & Lactobacillus algidus strain M 6 A9 & 853 & 92 & NR 028617.1 \\
BC & Lactobacillus apodemi strain ASB1 & 1012 & 89 & NR 042367.1 \\
BD & Bacillus wiedmannii strain FSL W8-0169 & 984 & 99 & NR152692.1 \\
BE & Micrococcus luteus strain NCTC 2665 & 887 & 77 & NR 075062.2 \\
FB & Candida parapsilosis strain IQMustafa31 & 558 & 95 & LT 577616.1 \\
\hline
\end{tabular}


Table 5: Colonial and Microscopic description of Fungi isolates

\begin{tabular}{|c|c|c|c|c|}
\hline Characters & $\begin{array}{l}\text { Isolates } \\
\text { FA }\end{array}$ & FB & FC & FD \\
\hline \multicolumn{5}{|c|}{ Colony Characteristics } \\
\hline Shape & Round & Flat & Flat & Flat \\
\hline Color & Creamy white & Yellowish green & Bluish green & White \\
\hline Color change & None & Greenish brown & Pale green & Brown \\
\hline Reverse color & No color & White & Blue brown & Colorless \\
\hline Texture & Smooth & Granulated & Velvety & Cottony \\
\hline Growth rate & Fast & Fast & Fast & Moderate \\
\hline \multicolumn{5}{|c|}{ Microscopic features } \\
\hline Hyphae & None & Septate and hyaline & Septate and branch & $\begin{array}{l}\text { Septate hyaline and } \\
\text { branched }\end{array}$ \\
\hline Spores & Budding cells & Conidia & Conidia & $\begin{array}{l}\text { Conidia: micro- and } \\
\text { macro-conidia }\end{array}$ \\
\hline $\begin{array}{l}\text { Shape of } \\
\text { spores }\end{array}$ & Oval & $\begin{array}{l}\text { globose } \\
\text { subglobose }\end{array}$ & Spherical & Spherical \\
\hline Phiallide & None & $\begin{array}{l}\text { Biseriate, directly to } \\
\text { vesicle }\end{array}$ & $\begin{array}{l}\text { Branched, } \\
\text { biverticillate }\end{array}$ & verticillate \\
\hline $\begin{array}{l}\text { Probable } \\
\text { organism }\end{array}$ & $\begin{array}{l}\text { Candida } \\
\text { Parapsilosis }\end{array}$ & Aspergillus flavus & Pencillium citrinum & $\begin{array}{l}\text { Fusarium } \\
\text { verticilloides }\end{array}$ \\
\hline
\end{tabular}

Table 6: Proximate Composition of Soymilk and Fermented Soymilk Samples

\begin{tabular}{|c|c|c|c|c|c|}
\hline \multirow[t]{2}{*}{ Parameters } & \multirow[t]{2}{*}{ Soymilk } & \multicolumn{4}{|c|}{ Fermented soymilk } \\
\hline & & PSSF & PRSF & SSSF & SRSF \\
\hline Moisture \% & $88.54 \pm 0.08^{b}$ & $70.65 \pm 8.48^{\mathrm{a}}$ & $71.47 \pm 6.80^{\mathrm{a}}$ & $64.14 \pm 4.40^{\mathrm{a}}$ & $63.26 \pm 3.99^{\mathrm{a}}$ \\
\hline Ash \% & $9.92 \pm 0.04^{\mathrm{b}}$ & $5.97 \pm 0.02^{\mathrm{a}}$ & $5.98 \pm 0.046^{\mathrm{a}}$ & $6.00 \pm 0.06^{\mathrm{a}}$ & $6.020 .04^{\mathrm{a}}$ \\
\hline СHO \% & $17.9 \pm 2.4^{\mathrm{b}}$ & $12.20 \pm 6.30^{\mathrm{a}}$ & $10.57 \pm 6.80^{\mathrm{a}}$ & $17.49 \pm 4.49^{\mathrm{a}}$ & $17.95 \pm 4.10^{\mathrm{a}}$ \\
\hline Total Protein \% & $8.178 \pm 0.06^{\mathrm{a}}$ & $12.53 \pm 0.71^{\mathrm{c}}$ & $11.90 \pm 0.07^{\mathrm{b}}$ & $12.18 \pm 0.16^{\mathrm{b}}$ & $12.62 \pm 0.12^{c}$ \\
\hline Crude Lipids \% & $0.20 \pm 0.03^{b}$ & $0.25 \pm 0.10^{\mathrm{b}}$ & $0.17 \pm 0.01^{\mathrm{a}}$ & $0.19 \pm 0.08^{\mathrm{ab}}$ & $0.16 \pm 0.02^{\mathrm{a}}$ \\
\hline Crude fibre \% & $1.921 \pm 0.02^{\mathrm{b}}$ & $1.24 \pm 0.02^{\mathrm{a}}$ & $1.26 \pm 0.01^{\mathrm{a}}$ & $1.24 \pm 0.03^{\mathrm{a}}$ & $1.25 \pm 0.03^{\mathrm{a}}$ \\
\hline $\begin{array}{l}\text { Calorific Value } \\
\mathrm{KJ} / \mathbf{1 0 0 g}\end{array}$ & $1478.59 \pm 7.2^{\mathrm{a}}$ & $4196 \pm 1145^{\mathrm{b}}$ & $3779 \pm 1130^{\mathrm{b}}$ & $5025 \pm 717^{\mathrm{b}}$ & $5164 \pm 666^{\mathrm{b}}$ \\
\hline $\begin{array}{l}\text { Metabolizable } \\
\text { Energy Kcal/kg }\end{array}$ & $353.97 \pm 1.68^{\mathrm{b}}$ & $108.7 \pm 24.0^{\mathrm{a}}$ & $92.5 \pm 27.1^{\mathrm{a}}$ & $125.67 \pm 15.6^{\mathrm{a}}$ & $128.21 \pm 15.8^{\mathrm{a}}$ \\
\hline $\begin{array}{l}\text { Metabolizable } \\
\text { Energy Protein } \\
\text { ratio }\end{array}$ & $4.32 \pm 0.01^{\mathrm{a}}$ & $8.10 \pm 2.19^{b}$ & $7.78 \pm 2.31^{\mathrm{b}}$ & $10.32 \pm 1.32^{\mathrm{b}}$ & $10.17 \pm 1.34^{\mathrm{b}}$ \\
\hline $\begin{array}{l}\text { Titrable acidity } \\
\text { (\%) }\end{array}$ & $0.050 \pm 0.01^{\mathrm{a}}$ & $1.63 \pm 0.03^{\mathrm{b}}$ & $1.80 \pm 0.01^{\mathrm{b}}$ & $1.76 \pm 0.02^{\mathrm{b}}$ & $2.37 \pm 0.02^{\mathrm{b}}$ \\
\hline
\end{tabular}

Values are means of triplicate readings \pm standard deviations. Values in the same row with different superscripts are significantly $(\mathrm{P}<0.05)$ different, $\mathrm{CHO}=$ Carbohydrate, $\mathrm{PSSF}=$ Non supplemented soymilk fermented on stationary bench

PRSF: Non supplemented soymilk fermented on rotary shaker

SSSF: Soymilk supplemented with sucrose and fermented on stationary bench

SRSF: Soymilk supplemented with sucrose and fermented on rotary shaker 
Table 7: Sensory evaluation of LEOHO treated Fermented Soymilk samples during storage

\begin{tabular}{|c|c|c|c|c|c|c|c|}
\hline \multirow[t]{2}{*}{ Samples } & \multirow[t]{2}{*}{ Conc } & \multicolumn{6}{|c|}{ Storage period (days) } \\
\hline & & 0 & 2 & 5 & 8 & 11 & 14 \\
\hline \multirow[t]{3}{*}{ PSSF } & $10 \%$ & $5.00^{\mathrm{a}}$ & $4.00^{\mathrm{b}}$ & $3.33^{b}$ & $3.33^{\mathrm{b}}$ & $3.33^{\mathrm{b}}$ & $2.33^{\mathrm{a}}$ \\
\hline & $5 \%$ & $5.00^{\mathrm{a}}$ & $4.33^{\mathrm{a}}$ & $3.67^{\mathrm{a}}$ & $3.67^{\mathrm{a}}$ & $3.67^{\mathrm{a}}$ & $2.33^{\mathrm{a}}$ \\
\hline & $\mathrm{C}$ & $4.67^{\mathrm{b}}$ & $2.67^{\mathrm{c}}$ & $1.33^{\mathrm{c}}$ & $1.33^{\mathrm{c}}$ & $1.00^{\mathrm{C}}$ & $1.00^{\mathrm{b}}$ \\
\hline \multirow[t]{3}{*}{ PRSF } & $10 \%$ & $5.00^{\mathrm{a}}$ & $4.00^{\mathrm{b}}$ & $3.33^{\mathrm{b}}$ & $3.33^{\mathrm{b}}$ & $3.33^{b}$ & $2.33^{\mathrm{a}}$ \\
\hline & $5 \%$ & $5.00^{\mathrm{a}}$ & $4.33^{\mathrm{a}}$ & $3.67^{\mathrm{a}}$ & $3.67^{\mathrm{a}}$ & $3.67^{\mathrm{a}}$ & $2.33^{\mathrm{a}}$ \\
\hline & $\mathrm{C}$ & $4.67^{\mathrm{b}}$ & $2.67^{\mathrm{c}}$ & $1.33^{\mathrm{C}}$ & $1.33^{\mathrm{c}}$ & $1.00^{\mathrm{C}}$ & $1.00^{\mathrm{b}}$ \\
\hline \multirow[t]{3}{*}{ SSSF } & $10 \%$ & $5.00^{\mathrm{a}}$ & $4.00^{\mathrm{b}}$ & $3.33^{b}$ & $3.33^{b}$ & $3.33^{b}$ & $2.33^{\mathrm{a}}$ \\
\hline & $5 \%$ & $5.00^{\mathrm{a}}$ & $4.33^{\mathrm{a}}$ & $3.67^{\mathrm{a}}$ & $3.67^{\mathrm{a}}$ & $3.67^{\mathrm{a}}$ & $2.33^{\mathrm{a}}$ \\
\hline & $\mathrm{C}$ & $4.67^{\mathrm{b}}$ & $3.67^{\mathrm{c}}$ & $1.33^{\mathrm{C}}$ & $1.33^{\mathrm{c}}$ & $1.00^{\mathrm{C}}$ & $1.00^{\mathrm{b}}$ \\
\hline \multirow[t]{3}{*}{ SRSF } & $10 \%$ & $5.00^{\mathrm{a}}$ & $4.00^{\mathrm{b}}$ & $3.33^{b}$ & $3.33^{b}$ & $3.33^{b}$ & $2.33^{\mathrm{a}}$ \\
\hline & $5 \%$ & $5.00^{\mathrm{a}}$ & $4.33^{\mathrm{a}}$ & $3.67^{\mathrm{a}}$ & $3.67^{\mathrm{a}}$ & $3.67^{\mathrm{a}}$ & $2.33^{\mathrm{a}}$ \\
\hline & C & $4.67^{b}$ & $3.67^{c}$ & $1.33^{c}$ & $1.33^{c}$ & $1.00^{c}$ & $1.00^{\mathrm{b}}$ \\
\hline
\end{tabular}

Each value represents mean of three sensory parameter (odor, color and texture) evaluated by five individuals on five point Hedonic scale. Values in the same column for a particular sample with different superscripts are significantly $(\mathrm{P}<0.05)$ different. $\mathrm{C}=$ Control, Conc $=$ Concentration. PSSF: Non supplemented soymilk fermented on stationary bench PRSF: Non supplemented soymilk fermented on rotary shaker SSSF: Soymilk supplemented with sucrose and fermented on stationary bench SRSF: Soymilk supplemented with sucrose and fermented on rotary shaker 
Table 8: Effect of leaf essential oil of Hoslundia opposita on the bacterial count of fermented soymilk samples during storage

\begin{tabular}{|c|c|c|c|c|c|c|c|c|c|c|c|c|}
\hline \multirow[t]{3}{*}{$\mathbf{P}$} & \multicolumn{12}{|c|}{ Bacterial count $\left(\mathrm{CFU} \mathrm{mL}^{-1}\right)$} \\
\hline & \multicolumn{3}{|l|}{ PSSF } & \multicolumn{3}{|l|}{ PRSF } & \multicolumn{3}{|l|}{ SSSF } & \multicolumn{3}{|l|}{ SRSF } \\
\hline & $5 \%$ & $10 \%$ & Ctrl & $5 \%$ & $10 \%$ & Ctrl & $5 \%$ & $10 \%$ & Ctrl & $5 \%$ & $10 \%$ & Ctrl \\
\hline $\mathbf{0}$ & $5.06 \pm 0.02^{\mathrm{h}, \mathrm{a}}$ & $5.06 \pm 0.02^{\mathrm{g}, \mathrm{a}}$ & $5.06 \pm 0.02^{\mathrm{a}, \mathrm{a}}$ & $4.52 \pm 0.02^{\mathrm{g}, \mathrm{a}}$ & $4.53 \pm 0.02^{\mathrm{i}, \mathrm{a}}$ & $4.52 \pm 0.02^{\mathrm{a}, \mathrm{a}}$ & $5.12 \pm 0.01^{1, \mathrm{a}}$ & $5.12 \pm 0.01^{\mathrm{h}, \mathrm{a}}$ & $5.12 \pm 0.01^{\mathrm{a}, \mathrm{a}}$ & $4.86 \pm 0.01^{1, \mathrm{a}}$ & $4.86 \pm 0.01^{\mathrm{I}, \mathrm{a}}$ & $4.86 \pm 0.01^{\mathrm{b}, \mathrm{a}}$ \\
\hline 1 & $2.20 \pm 0.10^{\mathrm{f}, \mathrm{b}}$ & $0.97 \pm 0.01^{\mathrm{a}, \mathrm{a}}$ & $7.41 \pm 0.04^{\mathrm{d}, \mathrm{c}}$ & $2.17 \pm 0.01^{\mathrm{f}, \mathrm{b}}$ & $0.92 \pm 0.01^{\mathrm{a}, \mathrm{a}}$ & $7.76 \pm 0.01^{\mathrm{d}, \mathrm{c}}$ & $2.17 \pm 0.01^{\mathrm{f}, \mathrm{b}}$ & $0.71 \pm 0.06^{\mathrm{a}, \mathrm{a}}$ & $9.25 \pm 0.02^{\mathrm{e}, \mathrm{c}}$ & $2.12 \pm 0.02^{\mathrm{f}, \mathrm{b}}$ & $0.62 \pm 0.04^{\mathrm{a}, \mathrm{a}}$ & $8.89 \pm 0.02^{\mathrm{e}, \mathrm{c}}$ \\
\hline 2 & $2.33 \pm 0.01^{\mathrm{g}, \mathrm{b}}$ & $1.28 \pm 0.02^{\mathrm{b}, \mathrm{a}}$ & $6.25 \pm 0.02^{\mathrm{c}, \mathrm{c}}$ & $2.25 \pm 0.05^{\mathrm{f}, \mathrm{b}}$ & $1.20 \pm 0.01^{\mathrm{b}, \mathrm{a}}$ & $6.77 \pm 0.02^{\mathrm{c}, \mathrm{c}}$ & $2.21 \pm 0.01^{\mathrm{g}, \mathrm{b}}$ & $1.16 \pm 0.02^{\mathrm{b}, \mathrm{a}}$ & $8.37 \pm 0.45^{\mathrm{c}, \mathrm{c}}$ & $2.17 \pm 0.02^{\mathrm{g}, \mathrm{b}}$ & $1.11 \pm 0.01^{\mathrm{b}, \mathrm{a}}$ & $7.57 \pm 0.02^{\mathrm{d}, \mathrm{c}}$ \\
\hline 3 & $2.38 \pm 0.02^{\mathrm{g}, \mathrm{b}}$ & $1.85 \pm 0.02^{\mathrm{c}, \mathrm{a}}$ & $5.73 \pm 0.04^{b, c}$ & $2.29 \pm 0.10^{\mathrm{f}, \mathrm{b}}$ & $1.62 \pm 0.02^{\mathrm{f}, \mathrm{a}}$ & $5.92 \pm 0.02^{b, c}$ & $2.27 \pm 0.02^{\mathrm{h}, \mathrm{b}}$ & $1.93 \pm 0.03^{\mathrm{f}, \mathrm{a}}$ & $7.12 \pm 0.02^{b, c}$ & $2.24 \pm 0.01^{\mathrm{h}, \mathrm{b}}$ & $1.87 \pm 0.02^{\mathrm{g}, \mathrm{a}}$ & $6.47 \pm 0.02^{\mathrm{c}, \mathrm{c}}$ \\
\hline 4 & $1.98 \pm 0.01^{\mathrm{e}, \mathrm{b}}$ & $1.82 \pm 0.06^{\mathrm{d}, \mathrm{a}}$ & ND & $1.93 \pm 0.03^{\mathrm{e}, \mathrm{a}}$ & $2.12 \pm 0.02^{\mathrm{h}, \mathrm{b}}$ & ND & $1.88 \pm 0.01^{\mathrm{e}, \mathrm{a}}$ & $2.05 \pm 0.01^{\mathrm{g}, \mathrm{b}}$ & $4.93 \pm 0.12^{\mathrm{a}, \mathrm{c}}$ & $1.78 \pm 0.01^{\mathrm{e}, \mathrm{a}}$ & $2.03 \pm 0.02^{\mathrm{h}, \mathrm{b}}$ & $4.23 \pm 0.01^{\mathrm{a}, \mathrm{c}}$ \\
\hline 5 & $1.81 \pm 0.04^{\mathrm{d}, \mathrm{a}}$ & $1.77 \pm 0.02^{\mathrm{e}, \mathrm{a}}$ & ND & $1.75 \pm 0.02^{\mathrm{d}, \mathrm{b}}$ & $1.69 \pm 0.01^{\mathrm{g}, \mathrm{a}}$ & ND & $1.72 \pm 0.02^{\mathrm{d}, \mathrm{a}}$ & $1.88 \pm 0.01^{\mathrm{e}, \mathrm{b}}$ & ND & $1.55 \pm 0.01^{\mathrm{d}, \mathrm{a}}$ & $1.75 \pm 0.01^{\mathrm{f}, \mathrm{b}}$ & ND \\
\hline 8 & $1.65 \pm 0.01^{\mathrm{c}, \mathrm{b}}$ & $1.42 \pm 0.02^{\mathrm{f}, \mathrm{a}}$ & ND & $1.52 \pm 0.03^{\mathrm{c}, \mathrm{b}}$ & $1.36 \pm 0.03^{\mathrm{e}, \mathrm{a}}$ & ND & $1.54 \pm 0.01^{\mathrm{c}, \mathrm{a}}$ & $1.62 \pm 0.03^{\mathrm{d}, \mathrm{b}}$ & ND & $1.35 \pm 0.02^{\mathrm{ca}}$ & $1.44 \pm 0.01^{\mathrm{e}, \mathrm{b}}$ & ND \\
\hline 11 & $1.49 \pm 0.03^{\mathrm{b}, \mathrm{b}}$ & $1.35 \pm 0.01^{\mathrm{f}, \mathrm{a}}$ & ND & $1.38 \pm 0.05^{\mathrm{b}, \mathrm{b}}$ & $1.31 \pm 0.01^{\mathrm{d}, \mathrm{a}}$ & ND & $1.34 \pm 0.02^{\mathrm{b}, \mathrm{a}}$ & $1.42 \pm 0.01^{\mathrm{c}, \mathrm{b}}$ & ND & $1.21 \pm 0.01^{\mathrm{b}, \mathrm{a}}$ & $1.23 \pm 0.01^{\mathrm{d}, \mathrm{a}}$ & ND \\
\hline 14 & $1.20 \pm 0.02^{\mathrm{a}, \mathrm{a}}$ & $1.26 \pm 0.03^{\mathrm{b}, \mathrm{b}}$ & ND & $1.17 \pm 0.02^{\mathrm{a}, \mathrm{a}}$ & $1.24 \pm 0.04^{\mathrm{c}, \mathrm{b}}$ & ND & $1.26 \pm 0.02^{\mathrm{a}, \mathrm{b}}$ & $1.18 \pm 0.01^{\mathrm{b}, \mathrm{a}}$ & ND & $1.01 \pm 0.01^{\mathrm{a}, \mathrm{a}}$ & $1.16 \pm 0.05^{\mathrm{c}, \mathrm{b}}$ & ND \\
\hline
\end{tabular}

Values are means \pm standard deviation of three independent experiments. Values were compared based on period of incubation and volume of essential oil applied for each category of fermented soymilk. Values with different superscripts along the same column, and on the same row for each category of sample are significantly different (p < 0.05).

PSSF: Non supplemented soymilk fermented on stationary bench

PRSF: Non supplemented soymilk fermented on rotary shaker

SSSF: Soymilk supplemented with sucrose and fermented on stationary bench

SRSF: Soymilk supplemented with sucrose and fermented on rotary shaker

$\mathrm{P}$ - Period of storage after addition of essential oil (days);

Ctrl - Control (Untreated samples);

ND - Not determined (bacterial counts were not determined because the samples had deteriorated) 
Table 9: Effect of leaf essential oil of Hoslundia opposita on the fungal count of fermented soymilk samples during storage

\begin{tabular}{|c|c|c|c|c|c|c|c|c|c|c|c|c|}
\hline \multirow[t]{3}{*}{$\mathbf{P}$} & \multicolumn{12}{|c|}{ Fungal count (CFU $\mathrm{mL}^{-1}$ ) } \\
\hline & \multicolumn{3}{|c|}{ PSSF } & \multicolumn{3}{|c|}{ PRSF } & \multicolumn{3}{|c|}{ SSSF } & \multicolumn{3}{|c|}{ SRSF } \\
\hline & $5 \%$ & $10 \%$ & Ctrl & $5 \%$ & $10 \%$ & Ctrl & $5 \%$ & $10 \%$ & Ctrl & $5 \%$ & $10 \%$ & Ctrl \\
\hline $\mathbf{0}$ & NG & NG & NG & NG & NG & NG & NG & NG & $0.20 \pm 0.00^{\mathrm{a}}$ & NG & NG & NG \\
\hline 1 & NG & NG & $0.30 \pm 0.00^{\mathrm{a}, \mathrm{b}}$ & $0.10 \pm 0.00^{\mathrm{a}, \mathrm{d}}$ & $0.13 \pm 0.06^{\mathrm{b}, \mathrm{b}}$ & $0.20 \pm 0.10^{\mathrm{a}, \mathrm{c}}$ & $0.07 \pm 0.06^{\mathrm{a}, \mathrm{a}}$ & $0.20 \pm 0.00^{\mathrm{c}}$ & $0.60 \pm 0.00^{\mathrm{b}, \mathrm{e}}$ & $0.13 \pm 0.06^{\mathrm{a}, \mathrm{b}}$ & $0.30 \pm 0.10^{\mathrm{a}, \mathrm{d}}$ & NG \\
\hline 2 & $0.07 \pm 0.06^{\mathrm{a}, \mathrm{a}}$ & $0.13 \pm 0.06^{\mathrm{a}, \mathrm{b}}$ & $0.67 \pm 0.12^{\mathrm{b}, \mathrm{f}}$ & $0.17 \pm 0.06^{\mathrm{b}, \mathrm{b}}$ & $0.23 \pm 0.06^{\mathrm{b}, \mathrm{c}}$ & $0.50 \pm 0.10^{\mathrm{b}, \mathrm{e}}$ & $0.20 \pm 0.00^{\mathrm{b}, \mathrm{c}}$ & NG & $1.00 \pm 0.00^{\mathrm{c,g}}$ & $0.27 \pm 0.12^{\mathrm{b}, \mathrm{d}}$ & $0.50 \pm 0.10^{\mathrm{b}, \mathrm{e}}$ & NG \\
\hline 3 & $0.17 \pm 0.06^{\mathrm{b}, \mathrm{b}}$ & $0.23 \pm 0.06^{\mathrm{b}, \mathrm{c}}$ & $1.30 \pm 0.10^{\mathrm{c}, \mathrm{g}}$ & $0.23 \pm 0.06^{\mathrm{c}, \mathrm{c}}$ & $0.07 \pm 0.06^{\mathrm{a}, \mathrm{a}}$ & $0.80 \pm 0.10^{\mathrm{c}, \mathrm{e}}$ & $0.23 \pm 0.06^{\mathrm{b}, \mathrm{c}}$ & NG & $1.30 \pm 0.10^{\mathrm{d}, \mathrm{g}}$ & $0.33 \pm 0.06^{\mathrm{b}, \mathrm{d}}$ & $0.80 \pm 0.10^{\mathrm{c}, \mathrm{d}}$ & NG \\
\hline 4 & $0.33 \pm 0.06^{\mathrm{c}, \mathrm{b}}$ & NG & ND & $0.30 \pm 0.00^{\mathrm{d}, \mathrm{b}}$ & $0.20 \pm 0.00^{\mathrm{a}, \mathrm{a}}$ & ND & $0.40 \pm 0.00^{\mathrm{c}, \mathrm{c}}$ & NG & $1.50 \pm 0.10^{\mathrm{e}, \mathrm{e}}$ & $0.33 \pm 0.02^{\mathrm{b}, \mathrm{b}}$ & $1.00 \pm 0.00^{\mathrm{d}, \mathrm{d}}$ & NG \\
\hline 5 & $0.20 \pm 0.00^{\mathrm{b}, \mathrm{b}}$ & NG & ND & $0.23 \pm 0.06^{\mathrm{c}, \mathrm{c}}$ & $0.13 \pm 0.06^{\mathrm{a}, \mathrm{a}}$ & ND & $0.20 \pm 0.00^{\mathrm{b}, \mathrm{b}}$ & NG & ND & $0.17 \pm 0.06^{\mathrm{a}, \mathrm{a}}$ & NG & ND \\
\hline 8 & $0.07 \pm 0.06^{\mathrm{a}, \mathrm{a}}$ & NG & ND & NG & NG & ND & NG & NG & ND & $0.10 \pm 0.00^{\mathrm{a}, \mathrm{b}}$ & NG & ND \\
\hline 11 & NG & NG & ND & NG & NG & ND & NG & NG & ND & NG & NG & ND \\
\hline 14 & NG & NG & ND & NG & NG & ND & NG & NG & ND & NG & NG & ND \\
\hline
\end{tabular}

Values are means \pm standard deviation of three independent experiments. Values were compared based on period of incubation and volume of essential oil applied for each category of fermented soymilk. Values with different superscripts along the same column, and on the same row are significantly different (p < 0.05 ).

PSSF: Non supplemented soymilk fermented on stationary bench

PRSF: Non supplemented soymilk fermented on rotary shaker

SSSF: Soymilk supplemented with sucrose and fermented on stationary bench

SRSF: Soymilk supplemented with sucrose and fermented on rotary shaker

$\mathrm{P}$ - Period of storage after addition of essential oil (days);

Ctrl - Control (Untreated samples);

ND - Not determined (bacterial counts were not determined because the samples had deteriorated);

NG - No growth (no fungal growth occurred on agar medium after incubation for seven days) 
Table 10: Sensitivity of bacterial Isolates to the leaf Essential oil of Hoslundia opposita

\begin{tabular}{lccc}
\hline \multirow{2}{*}{ Isolates } & \multicolumn{3}{c}{ Diameter zone of inhibition (mm) } \\
\cline { 2 - 4 } & $100 \%$ & $50 \%$ & $25 \%$ \\
\hline Bacillus wiedmannii strain FSL W8-0169 & $29.00 \pm 1.00^{\mathrm{bc}}$ & $21.00 \pm 1.00^{\mathrm{de}}$ & $15.67 \pm 2.08^{\mathrm{bcd}}$ \\
Micrococcus luteus strain NCTC 2665 & $32.00 \pm 2.00^{\mathrm{b}}$ & $26.00 \pm 1.00^{\mathrm{b}}$ & $21.33 \pm 1.53^{\mathrm{a}}$ \\
Lactobacillus algidus strain M 6 A9 & $43.33 \pm 3.06^{\mathrm{a}}$ & $31.33 \pm 1.53^{\mathrm{a}}$ & $17.00 \pm 1.00^{\mathrm{bc}^{*}}$ \\
Lactobacillus sakei strain NBRC 15893 & $46.33 \pm 1.53^{\mathrm{a}}$ & $31.67 \pm 1.53^{\mathrm{a}}$ & $19.00 \pm 1.00^{\mathrm{b}}$ \\
Lactobacillus apodemi strain ASB1 & $30.33 \pm 2.00^{\mathrm{bc}}$ & $23.67 \pm 1.53^{\mathrm{ac}}$ & $13.00 \pm 1.00^{\mathrm{e}^{*}}$ \\
Escherichia coli & $30.67 \pm 2.52^{\mathrm{bc}}$ & $23.00 \pm 2.00^{\mathrm{cd}^{*}}$ & $17.00 \pm 1.00^{\mathrm{bc}}$ \\
Shigella sp. & $28.00 \pm 2.00^{\mathrm{c}}$ & $19.33 \pm 0.58^{\mathrm{e}^{*}}$ & $14.33 \pm 1.53^{\mathrm{de}^{*}}$ \\
Staphylococcus aureus & $29.00 \pm 1.00^{\mathrm{bc}}$ & $16.00 \pm 1.00^{\mathrm{f*}}$ & $10.00 \pm 1.00^{\mathrm{f} *}$ \\
\hline
\end{tabular}

Values are means \pm standard deviations of readings taken in three planes. Values in the same column with different superscripts are significantly $(\mathrm{P}<0.05)$ different. *bacteriostatic.

Fungal growth in all the soymilk samples was highest at 9 hours of fermentation and dropped sharply to zero by the 24th hour. This shows strong inhibitory activities of the metabolites such as the $\mathrm{pH}$ reducing lactic, acetic, propionic and formic acids as well as hydrogen peroxide produced in the samples during fermentation (Schnurer and Magnusson, 2005; Siedler et al., 2019).

The majority of the bacterial isolates belonged to the genus Lactobacillus. Other species recorded were Bacillus, Staphylococcus, Micrococcus, Escherichia and Shigella. Lactobacillus sakei, which was one of the isolates is a facultative heterofermentative LAB comprising strains used as a starter culture (Armour et al., 2005); and is used for the production of bacteriocins such as saucisson for meat preservation (Bredholt et al., 2001), sakacin $\mathrm{P}$ which inhibits Listeria monocytogenes (Carvalho et al., 2009) and lactocin S (Mortvedt et al., 1991). Lactobacillus algidus is a group $\mathrm{B}$ lactobacilli that was first reported by Kato et al. (2000) as a fastidious, meat-derived, psychrophilic lactic acid bacterium implicated in spoilage of meat. L. apodemi was also reported as a novel species in 2006 (Osawa et al., 2006).

Bacillus weidmannii was first isolated from dairy milk and dairy environments. It is a member of the Bacillus cereus group which includes pathogenic and non-pathogenic strains as well as food spoilage organisms (Miller et al., 2016). This makes its isolation from the fermented soymilk samples significant as it may be responsible for spoilage and may constitute a potential threat to the health of consumers. Micrococcus luteus may have contaminated the soymilk during processing or may be present on the soybean since it occurs in the soil, dust, water, air and as part of the normal flora of human skin. It was first isolated by Alexander Flemming in 1928. It has also been isolated from foods such as milk, cheese, meat and cassava (Laurie, 2015) that were contaminated through handling. Staphylococcus aureus, Escherichia coli and Shigella sp are contaminants that can constitute a potential health risks to consumers of the product. Staphylococcus aureus, is a normal flora of human and animal skin and can contaminate foods during processing. Its presence in foods is very important because it causes food borne diseases due to the production of toxins (Kadariya, et al., 2014). Escherichia coli is a member of the gastrointestinal flora. Its detection in food signifies fecal contamination. Most strains are harmless, but some including shiga-toxin producing E. coli O157:H7 cause serious food poisoning and it's frequently associated with milk and dairy products (WHO, 2018). Shigella cause an acute disease involving the large and distal small intestine that is characterized by diarrhoea, vomiting, and abdominal pain (Yousefi et al., 2018).

All the fungal isolates are important spoilage organisms with implications in food-borne diseases. The yeast Candida parapsilosis is among other fungi that commonly cause spoilage of yoghurt and other dairy product (Akabanda et al., 2013). It is a commensal on human skin and has been isolated from human hands, soil, insects, domestic animals and marine environments. It was considered non-pathogenic but later found to cause blood sepsis as well as wound and tissue infections (Trofa et al., 2008). It is the second most common pathogen in superficial candidiasis after C. albicans (Feng et al., 2012).

The molds Aspergillus, Penicillium and Fusarium secrete mycotoxins in addition to changing the aesthetic nature of foods. Aspergillus flavus is a common saprophytic fungus that is also pathogenic to many crops such as cereals, legumes and tree nuts. They produce aflatoxin, a carcinogenic mycotoxin and also cause aspergilloses in humans (Saori and Keller, 2011). Penicillium critinum is also a contaminant of agricultural products and have been isolated from cereals and spices. They 
secrete a number of secondary metabolites including citrinum, a nephrotoxic mycotoxin (Houbrraken et al., 2010). Fusarium verticilloides also produces the mycotoxin fumonisin in addition to fusarin $\mathrm{C}$ which is a mutagenic chemical (Ortiz et al., 2015)

After fermentation, there was significant increase in the total proteins (54\%), calorific value (71\%) and titratable acidity (98\%) of the milk while the moisture (29\%), ash (40\%), carbohydrate (41\%, crude lipids (20\%), crude fibre (35\%) and metabolizable energy (74\%) were significantly reduced. This result which is similar to that reported by Obadina et al. (2013) shows an improvement in the nutritional composition due to fermentation particularly with regard to the protein content which is a major nutrient, and the main reason for consumption of fermented soymilk.

The acceptance rating of the LEOHO treated fermented soymilk was considerably significantly higher than the untreated samples. This improvement in acceptance further attests to the preservative properties of the LEOHO.

The preservative effect of the LEOHO was demonstrated with a general reduction in the bacterial load of the fermented soymilk samples after treatment. In addition, a residual effect occurred as there was no significant increase in the population of bacteria recovered during storage. This preservative effect is a result of the antimicrobial activities of the oil as reported earlier (Gundidza et al., 1992; Ojo and Anibijuwon, 2010).

The fungal growth was generally low in the fermented soymilk samples. No growth was obtained from the samples treated with LEOHO until the 2nd and 3rd day of storage while only one of the control samples had fungal growth immediately after fermentation. The fungal load was also low during fermentation and this was carried over to the storage period accounting for the initial zero counts. In addition, the LEOHO may have inhibited fungal growth as its antifungal activities has been demonstrated earlier (Gundidza et al., 1992; Zolo et al., 1998). The growth that occurred shortly during storage also shows that the oil exhibited fungi-static activity at the concentration used.

The LEOHO significantly inhibited the bacterial isolates at a concentration as low as $25 \%$ and with cidal effects at higher concentrations. There is a dearth of information on the antimicrobial activity of the LEOHO in literature. However activities against some bacteria including many Bacillus species such as B. cereus, B. pumilus, B. subtilis, and others such as Staphylococcus aureus,
Enterobacter feacalis (Kapoor et al., 2015), and Lactobacillus acidophilus (Ocheng et al., 2015) had been reported.

\section{Conclusions}

Fermentation of soymilk yielded a product with improved nutritional composition and consumer acceptability. The leaf essential oil of Hoslundia opposita significantly inhibited growth of microorganisms and all the microbial isolates were found to be sensitive to the oil. This work therefore recommends the production of yoghurt-like fermented soymilk as a nutritious and refreshing beverage and its preservation using LEOHO after ascertaining its safety.

\section{References}

Adegoke, G. O., Gbadamosi, R., Evwoerhurhoma, F., Uzo-Peters, P. I., Falode, K. O., Mandy, O. and Skura, B. (2012). Protection of maize (Zea mays) and soybean (Glycine max) using Aframonum Donielli. Journal of European Food Research Technology. 214: 408-411.

Agboke, A.A., Uduma, E., Osonwa, C., Emmanuel, O.andIbezim, C. (2011). Evaluation of Microbiology quality of some soybean milk products consumed in Nigeria. Prime Journals. 1(2): $25-30$

Akabanda F, Owusu-Kwarteng J, Tano-Debrah K, Glover R.LK, Nielsen DS, Jespersen L. (2013). Taxonomic and molecular characterization of lactic acid bacteria and yeasts in nunu, a Ghanaian fermented milk product. Food Microbiology, 34: 277-283.

Akolade, J.A., Usman, L.A, Okereke O.E. and Muhammed, N.O. (2014). Antidiabetic potentials of essential oil extracted from the leaves of Hoslundia opposite Vahl. Journal of Medicinal Food 17(10) https://doi.org/10.1089/jmf.2014.0118

AOAC. (2003). Official Methods of Analysis of the Association of Officials Analytical Chemists (17th Ed.). Association of Official Analytical Chemists, Arlington Virginia.

Armour, S., Dufour, E., Zagorec, M., Chaillou, S.P. and Chavallier, I. (2005) Characterization and selection of Lactobacillus sakei strains isolated from traditional dry sausage for their potentials as starter cultures. Food Microbiology 22(6): 529 -538 .

Babarinde, S.A., Pitan, O.O.R., Olatunde, G.O. and Ajala, M.O. (2017) Chemical composition of the essential oil of Nigerian grown Hoslundia opposite Vahl. (Lamiaceae) dried leaves and its 
bioactivity against cowpea seed Bruchid. Chemistry and Biodiversity 14(6):

Bredholt, S., Nesbakken, T. and Holick, A. (2001) Industrial application of antilisterial strain of Lactobacillus sakei as protective culture and its effect on the sensory acceptability of cooked sliced vacuum packaged meats. International Journal of Food Microbiology 66(3): 191 - 196.

Carvalho, K.T.G., Bambirra, F.H.S., Kruger, M.F., Barbosa, M.S., Oliviera, J.S., Santos, A.M.C. (2009) Antimicrobial compounds produced by Lactobacillus sakei Subs. Sakei a bacteriocinogenic strain isolated from a Brazilian meay product. Journal of Industrial Microbiology and Biotechnology 37(4): 381 390.

Djenane, D., Yangueela, T., Gomez, D. and Roncales, P. (2012) Perspectives on the use of essential oils as antimicrobials against Campylobacter jejuni CECT 7572 in retail chicken meats packaged in micro aerobic atmosphere. Journal of Food Safety 32: 37 - 47.

Etiosa O.R., Nnadozie B.C. and Anuge B. (2017) Mineral and Proximate Composition of Soya Bean. Asian Journal of Physical and Chemical Sciences 4(3): 1 - 6 .

Feng X., Ling B., Yang G., Yu X., Ren D., Yao Z. (2012) "Prevalence and distribution profiles of Candida parapsilosis, Candida orthopsilosis and Candida metapsilosis responsible for superficial candidiasis in a Chinese university hospital". Mycopathologia. 173(4): 229-234. https://doi:10.1007/s11046-011-9496-5

Gundidza, G.M., Deans, S.G. Syoboda, K.P. and Mavi S. (1992) Antimicrobial activity of essential oil from Hoslundia opposita. Central Africa Journal of Medicine 38(7): 290 - 293.

Gutlekin,F., Yasar, S., Gurbuz, N. and Ceyhan, B.M. (2015) Food additives of public concern for their carcinogenicity. Journal of Nutritional Health and Food Science 6(4): 1 - 6 http://dx.org/10.15226/jnhfs.2015.00149

Horáčková Š., Mühlhansová A., Sluková M., Schulzová V., Plocková M. (2015) Fermentation of soymilk by yoghurt and bifidobacteria strains. Czech Journal of Food Science. 33: 313-319.

Houbraken, J.A.M.P., Frisvad, J.C. and Samson, R.A. (2010) Taxonomy of Penicillium ctrinum and related species. Fungal Diversity 44: 117 133.

Ishibashi, N. and Shimamura, S. (1993) Bifidobacteria: Research and Development in Japan. Food Technology 6: 126 - 136.
Kadariya, J., Tara C. S., and Dipendra T. (2014) Staphylococcus aureus and staphylococcal foodborne disease: An ongoing challenge in public health. BioMed Research International https://doi:10.1155/2014/827965Retrieved on $10^{\text {th }}$ October, 2019.

Kapoor A., Gurdeep K.and Rajinder K. (2015) Antimicrobial activity of different herbal plants extracts: A Review. World Journal of Pharmacy and Pharmaceutical Sciences 4(7): 422 -459

Kato, Y., Sakala, R.M., Hayashidani, H., Kiuchi, A., Kaneuchi, C. and Ogawa, M. (2000) Lactobacillus algidus sp. Nov., a psychrophilic lactic acid bacterium isolated from vacuum packaged refrigerated beef. International Journal of Systematic and Evolutionary Microbiology 50(3): $1143-1149$.

Laurie K. (2015) Environmental Isolates Case Files: Micrococcus luteus. Microbiologics Blog www.microbiologics.comRetrieved on $8^{\text {th }}$ October, 2019.

Miller R.A., Beno S.M. and Kovac J. (2016) Bacillus weidmannii sp. Nov., a psychrotolerant and cytotoxic Bacillus cereus group species isolated from dairy foods and dairy environments. International Journal of Systematic and Evolutionary Microbiology 66(11): 4744 - 4753.

Mora-Escobedo, Rosalva, María Del Carmen Robles-Ramírez, Alma Delia Román-Gutiérrez, Javier Castro-Rosas, CiroBaruchs MuñozLlandes and Fabiola Araceli Guzmán-Ortiz (2018) Peptides and Microorganisms Isolated from Soybean Sources with Antimicrobial Activity, Soybean - Biomass, Yield and Productivity, Minobu Kasai, IntechOpen, DOI: 10.5772/intechopen.81243. Available from: https://www.intechopen.com/books/soybeanbiomass-yield-and-productivity/peptides-andmicroorganisms-isolated-from-soybean-sourceswith-antimicrobial-activity

Mortvedt, C.I., Nissen-Meyer, K. and Nes I.F. (1991) Purification and amino acid sequencing of lactocin S, a bacteriocin produced by Lactobacillus sakei L45. Applied and Environmental Microbiology 57(6): 1829 - 1834

Obadina, A.O., Akinola, O.J., Shittu, T.A. and Bakare, H.A (2013) Effect of Natural Fermentation on the Chemical and Nutritional Composition of Fermented Soymilk Nono Nigerian Food Journal31(2): 91-97

Ocheng, F., Bwanga, F., Joloba, M., Softrata, A., Azeem, M., Putsep, K., et al. (2015) Essential oils from Ugandan aromatic medicinal plants: Chemical composition and Growth inhibitory effects on oral pathogens. Evidence-Based Complementary and Alternative Medicine. 
https://doi.org/10.1155/2015/230832 Retrieved on $8^{\text {th }}$ October, 2019.

Ojo O.O. and Anibijuwon, I.I. (2010) Studies on extracts of three medicinal plants of Southwestern Nigeria: Hoslundia opposita, Lantana camaraand Cymbopogoncitratus. Advances in Natural and Applied Sciences 4(1): 93+

Ortiz, C.S., Richards, C., Terry, A., Parra, J. and Shim, W.B. (2015) Genetic variability and geographical distribution of mycotoxigenic Fusarium verticilloides strains isolated from maize fields in Texas. Plant Pathology Journal 31(3): $203-211$.

Osawa R., Fujisawa T. and Pukall R. (2006) Lactobacillus apodemi sp. Nov., a tannase producing species isolated from wild mouse feaces. International Journal of Systematic and Evolutionary Microbiology 56(7): 1693 - 1696.

Osundahunsi, O.F., Amosu, D. and Ifesan, B.O.T. (2007) Quality evaluation and acceptability of soy-yoghurt with different colours and fruit flavours. American Journal of Food Technology 2: $273-280$

Owusu-Kwarteng, J., Akabanda, F., Johansen, P., Jesperson, L. and Nielsen D.S. (2017) Nunu, A West African Fermented Yogurt-Like Milk Product In: Yogurt in Health and Disease Prevention. Academic press Pages 275-283

Pandey, A.K., Singh, P., Mohan, M. and Tripathi, N.N. (2015) Chemical and antimicrobial activity of Nepeta hindostana (Roth) Haines from India. Records of Natural Products9:224 - 233.

Rastogi, A. and Singh, G. (1989). Effect of addition of full fat soy flour of different varieties on quality characteristics and bread making quality of white flour. Bulletin of Grain Technology27: 26-34.

Rathi, M., Upadhyay, N., Dabur, R. S. and Goyal A. (2015) Formulation and physico-chemical analysis of whey-soymilk dahi. Journal of Food Science and Technology 52(2): 968-975 https://doi:10.1007/s13197-013-1074-z

Riaz, M.N. (1999). Healthy baking with soy ingredients. Cereal Foods World. 44: 136-139.
Sadri A.S.(2017). Antimalarial effects and other properties of Hoslundia opposita - A Review. Global Journal of Pharmacy and Pharmaceutical Science 4(3): 555636 https://doi:10.19080/GJPPS.2017.04.555636

Saori, A. and Keller, N.P. (2011) Aspergillus flavus. Annual Review of Phytopathology 49: 107 $-133$.

Schnurer, J. and Magnusson, J. (2005) Antifungal lactic acid bacteria as biopreservatives. Trends in Food Science and Technology 16: 70 - 78.

Siedler, S., Balti, R. and Neves A.R. (2019) Bioprotective mechanisms of lactic acid bacteria against fungal spoilage of food. Current Opinion in Biotechnology 56:138-146 https://doi.org/10.1016/j.copbio.2018.11.015

Shurtleff, W. and Aoyagi A. (2013) History of cheese, cream cheese and sour cream alternatives (with or without soy) (1896 - 2013). Soyinfo Center, Lafayette California www.soyinfocenter.com.

Silva, C.F.B., Santos, F.L., Santana, L.R.R., Silva, M.V.L. and Conceicao, T.A. (2018) Development and characterization of a soymilk kefir-based functional beverage. Food Science and Technology 38(3):

Stefanakis, M.K., Touloupakis, E. Anastopoulos, E. Ghanotakis, D., Katerinopoulos, H.E. and Makridis, P. (2013) Antibacterial activity of essential oils from plants of the genus Origanum. Food Control 34: 539 - 546.

Subrota, H., Shilpa, V., Brij, S., Vandna, K. and Surajit, M. (2013). Antioxidative activity and polyphenol content in fermented soy milk supplemented with WPC-70 by probiotic Lactobacilli. International Food Research Journal. 20(5): 2125-2131

Trofa D., Gacser A. and Nosachuk J.D. (2008) Candida parapsilosis, an emerging fungal pathogen. Clinical Microbiology Reviews 24(4): $606-625$.

Useh Mercy Uwem, AdebiyiAdedayoBabafemi, Dauda Mary Sunday, (2017) Proximate Composition, Phytoconstituents and Mineral Contents of Soybean (Glycine Max) Flour Grown and Processed in Northern Nigeria. Advances in Applied Sciences. 2(4): 48-53.

Usman, L.A., Zubair, M.F., Adebayo, S.A., Oladosu, L.A., Muhammad, N.O. and Akolade J.O. (2010) Chemical composition of leaf and fruit essential oil of Hoslundia opposite Vahl. grown in Nigeria. Amerrican-Eurasian Journal of Agric and Environmental Science 8(1): 40 43.

Wang, Y.C., Yu, R.C. and Chou, C.C. (2006) Antioxidative activities of soymilk fermented 
with lactic acid bacteria and bifidobacteria. Food Microbiology 23: 128 - 135.

WHO, (2018) E.coli http://www.who.int>newsroom $>$ fact-sheets $>$ detai/>e-coliRetrieved on $10^{\text {th }}$ October, 2019.

www.factfish.comfactfishsoybeans, yield for Nigeria Retrieved 05/11/2019

Yousefi, M., Dehesh ,M.M. ,Askarpour, S. and Saeidi R.A. (2018) Food Poisoning Outbreak by Shigella boydii in Kerman-Iran, Arch. Clinical and Infectious Diseases 13(6):e82350. doi: 10.5812/archcid.82350.

Zielinska, D. and Kolozym-Krajewska (2018) Food origin lactic acid bacteria may exhibit probiotic properties: Review. Biomedical Research International.

https://doi.org/10.1155/2018/5063185

Zollo, P.H.A., Boyit, L., Tchoumbongnang, F., Menut, C., Lamaty, G. and Bouchet, P.F. (1998) Aromatic plants of tropical Central Africa Part XXXII. Chemical composition and antifungal activity of thirteen essential oils from aromatic plants of Cameroon. Chemistry 13:2-107 